\title{
FENNTARTHATÓ BOLDOGSÁG? SZUBJEKTÍV JÓLLÉT ÖKOLÓGIAI HATÁROK KÖZÖTT
}

\section{SUSTAINABLE HAPPINES? SUBJECTIVE WELLBEING WITHIN PLANETARY BOUNDARIES}

\author{
Csutora Mária \\ egyetemi tanár, Budapesti Corvinus Egyetem \\ maria.csutora@uni-corvinus.hu
}

\begin{abstract}
ÖSSZEFOGLALÁS
Az ökológia szolgáltatások-szubjektív jóllét-anyagi fogyasztás kapcsolatának vizsgálata a környezet-gazdaságtan és a jólléti gazdaságtan alapvető kérdése. Megvalósítható-e olyan életstílus, amely magas jólléti szintet eredményez, miközben anyagi fogyasztása és ökológiai hatása visszafogott? És ha igen, jelen van-e ezen életstílus a jelenlegi társadalomban? Ezekre a kérdésekre kereste a választ 2017 elején zárult kutatásunk. Eredményeink szerint létezik olyan társadalmi klaszter, amely magas életminőséget tud elérni az ökológiai lábnyom mérsékelt szintje mellett, sőt a legmagasabb szubjektív jóllétet nem is a legmagasabb anyagi fogyasztással és ökológiai lábnyommal jellemezhető klaszterben mértük. Ez megerősíti azon korábbi eredményeket, hogy a szubjektív jóllét növelésének ugyan vannak anyagi feltételei, de az anyagi jóllét növelése nem vezet feltétlenül a tapasztalati boldogság és elégedettség növekedéséhez.
\end{abstract}

\section{ABSTRACT}

The examination of the relationship between material consumption of ecological services-subjective well-being-is a fundamental issue of environmental economics. Is it possible to achieve a lifestyle that results in a high level of wellbeing while its ecological impact is restrained? And if so, is this lifestyle present in current society? These are the questions that our research, completed in early 2017, sought to answer. According to our results, there is a social cluster that can achieve a high quality of life at a moderate ecological footprint level. In fact, the highest subjective well-being was not measured in the highest material consumption and ecological footprint cluster. This confirms previous findings that while there are material conditions for increasing subjective well-being, increasing material well-being does not necessarily lead to high level of subjective happiness and satisfaction.

Kulcsszavak: szubjektív jóllét, ökológiai lábnyom, elégedettség, boldogság, jövedelem, jólléti indikátorok, reprezentatív felmérés

Keywords: subjective wellbeing, ecological footprint, life satisfaction, happiness, income, wellbeing indicators, representative survey 


\section{BEVEZETÉS}

Nem tudjuk pontosan, hol vannak Földünk ökológiai korlátai, és meddig tolhatóak ki, de léteznek korlátok, ezek között próbálunk egyre jobb életminőséget elérni. A tudományos közösség általában egyetért abban, hogy a Föld ökológiai szolgáltatásai a jelenlegi technológiai színvonal mellett nem tudják a hétmilliárdos lakosság számára ugyanazt az anyagi jólléti szintet biztosítani, amely a nyugat-európai társadalmakat jellemzi, anélkül, hogy ne veszélyeztetnénk az életfenntartó ökológiai rendszereket (Wackernagel et al., 2004). Az éghajlatváltozás 2 Celsius-fokon belül tartása is ambiciózus cél az uralkodó gazdasági tendenciák mellett. Ugyanakkor fejlődni is szeretnénk, a kormányok politikájának sikerességét a jóllét szintjének állandó emelkedése alapján ítéljük meg. A jóllét értelmezése sokat változott az elmúlt évtizedekben, míg korábban szinte kizárólag anyagi értelemben használtuk, és a jövedelemmel közelítettük, addig mára elötérbe került a többdimenziós értékelés, benne a közvetlen megkérdezésén alapuló mérések is.

A fenntartható gazdasági növekedést mára felváltotta a fenntartható fejlődés mint minőségi javulás fogalma, s ezek mintájára definiálható a fenntartható boldogság vagy fenntartható elégedettség fogalma is. Catherine O’Brien (2010) szerint a fenntartható boldogság a boldogságra való törekvés olyan módja, amely nem más egyének, a környezet vagy a jövő generációk rovására történik. Ez azt jelenti, hogy életminőségünket oly módon szeretnénk javítani, hogy az

- ne veszélyeztesse az alapvető ökológiai fenntartó rendszerek müködését,

- ne növelje az adott generáción belül a társadalmi egyenlötlenséget,

- és ne a jövő generációk kárára történjen.

Ez az anyagi fogyasztás korlátok között tartását jelenti. Az ökológia szolgáltatások-szubjektív jóllét-anyagi fogyasztás kapcsolatának vizsgálata a környezet-gazdaságtan és a jólléti gazdaságtan alapvető kérdése. Megvalósítható-e olyan életstílus, amely magas jólléti szintet eredményez, míg ökológiai hatása korlátozott? És ha igen, jelen vannak-e ezen életstílus csírái a jelenlegi társadalomban? Ezekre a kérdésekre kereste a választ 2017 elején zárult kutatásunk.

\section{A JÓLLÉT OBJEKTÍV ÉS SZUBJEKTÍV INDIKÁTORAI}

Mielőtt rátérnénk kutatásunk részleteire, szenteljünk egy kis időt a jóllét és az ökológiai lábnyom összefüggésére és mérésének sajátosságaira.

Az ökológiai lábnyom az anyagi fogyasztással, az általunk elfogyasztott termékek mennyiségével függ össze, annak lineáris függvénye (Tóth et al., 2018). Eltérő fogyasztási minták ökológiai lábnyoma is eltérő, ugyanazt a jövedelmet 
el lehet költeni magas ökológiai hatással és alacsony ökológiai hatással járó tevékenységekre is. Például néhány millió forintból lehet vásárolni mükincseket, megtakarításként félretenni, vagy oktatásra költeni (alacsony ökológiai lábnyom), vagy tengeren túli utazásra menni, esetleg még egy autót vásárolni (magas ökológiai lábnyom).

Ugyanígy a jövedelmet el lehet költeni oly módon, amely jelentősen javítja az egyének érzékelt jólléti szintjét, de el lehet költeni úgy is, hogy nem vezet tartós boldogságnövekedéshez. Utóbbira példa a szerencsejátékosok költekezése, de az is, hogy a világ egy részén az életet megrövidítő legfontosabb kockázati tényező már a magas testtömegindex, vagyis az ételek túlzott fogyasztása. Ez a fajta tévfogyasztás rövid távon ugyan hozzájárulhat a pillanatnyi boldogsághoz, de nem vezet tartós jólléti növekedéshez.

A fenntartható boldogság ökológiai és jólléti dimenzióit ábrázolva a következő egyszerủ mátrixot kapjuk.

1. táblázat. Az ökológiai fenntarthatóság és a szubjektív jóllét kategóriái

\begin{tabular}{|c|c|c|c|}
\hline & & \multicolumn{2}{|c|}{ Ökológiai lábnyom } \\
\hline & & Alacsony & Magas \\
\hline \multirow{2}{*}{ Jóllét } & Alacsony & (a) fenntartható boldogtalanság & (b) fenntarthatatlan boldogtalanság \\
\hline & Magas & (c) fenntartható boldogság & (d) fenntarthatatlan boldogság \\
\hline
\end{tabular}

Kocsis Tamás (2010) az országok ökológiai lábnyomát és jólléti szintjét vizsgálta hasonló dimenziók mentén, és megállapította, hogy a magas jólléti szint általában magas ökológiai lábnyommal jár együtt: (d) fejlődési út. Az alacsony ökológiai lábnyomú országok jelentős része ugyanakkor az (a) fenntartható boldogtalanság útvonalát követi, ahonnan szeretnének elmozdulni. Az országok mutatói tehát nem adnak okot túl sok optimizmusra a szubjektív jóllét és az ökológiai lábnyom összehangolását illetően. Az egyénekre fókuszáló vizsgálatok szerencsére sokkal biztatóbb megállapításokra jutottak.

Kirk Warren Brown és Tim Kasser (2005) az ökológiailag felelös viselkedés és a szubjektív jóllét közötti kapcsolatot vizsgálta. Megállapították, hogy az önkéntes egyszerűség elve szerint élők alacsonyabb ökológiai lábnyommal rendelkeznek, és magasabb az élettel való elégedettségük szintje. A belső értékorientációban találták meg a magyarázatot az élettel való elégedettség fokozódására. Mintavételük azonban nagyon korlátozott és specifikus volt. Ruut Veenhoven $(2008,39$.) úgy találta, hogy „,a fenntartható fogyasztás irányába történő elmozdulás legalábbis ideiglenesen enyhén csökkenti a boldogságot, ám luxusfogyasztás nélkül is elég boldogan élhetünk". 
A jövedelem növelésének mint életcélnak a szubjektív jóllétre gyakorolt hatása önmagában is ellentmondásos. A kérdést vizsgálják a közgazdaságtan és a pszichológia egyes irányzatai is. Kutatási módszertanuk hasonló, nagymintás reprezentatív mintán alapuló sokváltozós elemzéseket végeznek. Érdekes viszont, hogy következtetéseikben lényeges eltérések adódnak abban a tekintetben, hogy a jövedelmi helyzetnek mekkora a jelentősége a szubjektív jóllét emelésében. A közgazdasági tanulmányok általában hangsúlyozzák a két mutató közötti szignifikáns kapcsolatot, de egyre nagyobb szerepet kap a nem anyagi tényezők vizsgálata is, lásd Lelkes Orsolya (2014), Molnár György és Kapitány Zsuzsa (2014). A pszichológusok - bár elismerik a jövedelem és szubjektív jóllét közötti asszociáció jelenlétét - figyelmeztetnek a kapcsolat visszásságaira is (Kasser-Ryan, 1996, 2001; Nickerson et al., 2003). A pénzben kifejezett életcélok esetleges romboló jellegére mutat rá Martos Tamás és Kopp Mária $(2012,566$.), mikor megállapítják, hogy „az életorientációban az extrinzik célok felé való orientáció - ezek közé tartozik az anyagi jóllét növelésére való törekvés is - hozzájárulhat a pillanatnyi hangulat és elégedettség javításához, hosszú távon azonban költségeket rejt magában”.

A közgazdaságtanban vita alakult ki a téma kapcsán. Richard A. Easterlin (1973) - a boldogság közgazdaságtanának egyik elindítója - rámutatott, hogy az átlagos nemzeti boldogság az USA-ban az idők során változatlan maradt annak ellenére, hogy az egy före jutó GDP nőtt, habár mikroszinten pozitív korreláció mérhető az egyének élettel való elégedettsége és jövedelmi helyzete között. Ruut Veenhoven és Michael R. Hagerty ellenben azt állapította meg, hogy ,a gazdag nemzetekben és a néhány szegény nemzetben, amelyekre vonatkozóan rendelkezésre állnak adatok, enyhe emelkedés volt mérhető a boldogság szintjében" (2006, 421.). Christian Bjørnskov és szerzőtársai szerint $(2008,317$.$) ,a jelenlegi$ GDP-növekedés nem befolyásolja a jólét alakulását, a GDP-növekedés felgyorsulása igen. Továbbá a szomszédos országoknál nagyobb GDP-növekedés és a kormányzati fogyasztás erőteljesebb növekedése pozitív tendenciákat idéz elő az élettel való elégedettség terén".

Továbbá, egy adott országon belül többféle életstratégia közül választhatnak az egyének, a boldogság növelésének nem az egyetlen útja az anyagi fogyasztás növelése. Ahogy az országok között jelentős diverzitást találhatunk a jövedelem és szubjektív jóllét összefüggésében, feltételezhetjük, hogy ugyanez a diverzitás fennáll egyéni szinten is. Márpedig a különböző egyéni stratégiák ökológiai lábnyom vonzata is eltérő. Egyéni szintủ vizsgálatoknál még nagyobb valószínüséggel várható, hogy találunk kevésbé anyagias és kisebb ökológiai lábnyommal járó, ugyanakkor boldogító életstratégiákat. Keressük tehát azokat a fogyasztási mintákat, amelyek a tapasztalati jóllétet, azaz az elégedettséget és boldogságot növelik, miközben ökológiai hatásuk mérsékelt marad.

Mielött rátérnénk saját kutatásunk ismertetésére, szánjunk néhány bekezdést a jóllét és az ökológiai lábnyom mérésének alapvető kérdéseire. 


\section{A JÓLLÉT ÉS AZ ÖKOLÓGIAI HATÁSOK MÉRÉSE}

Az egyének jóllétét régebben jövedelmi helyzetükkel közelítették, és mérését kizárólag az anyagi jólétre korlátozták. Az anyagi javak fogyasztása hatással van, de nem egyedüli meghatározó tényezője az egyének szubjektív életminőségének. A Központi Statisztikai Hivatal (KSH) mérései alapján az anyagi jólétet a szubjektív jóllét valószínűségi feltételének tekinthetjük. Az egydimenziós mérést később felváltotta egy árnyaltabb megközelítés, ahol kilenc indikátorral közelítette az európai statisztikai rendszer az életminőség különböző dimenzióit (anyagi életkörülmények, egészség, munka- vagy egyéb fötevékenység, szabadidő és társadalmi kapcsolatok, oktatás, részvétel a döntéshozatalban, gazdasági és fizikai biztonság, természeti és lakókörnyezet, az életminőség szubjektív értékelése). A szubjektív jólléti mutatók a szubjektíven érzékelt életminőség mérőszámai.

A jóllét objektív mutatói közvetve kapcsolatban vannak az ember által érzékelt tapasztalati jólléti szinttel. A jóllét szintjére azonban közvetlenül is rá lehet kérdezni egyszerủ kérdésekkel. Például: Mennyire elégedett Ön általában az életével? Értékelje 0-10-ig terjedő skálán. Vagy: Mennyire érzi Ön magát általában boldognak? Az ezekre a kérdésekre adott - nagymintás reprezentatatív mintán alapuló - válaszokból országos szinten összeáll a szubjektív jóllét két indikátora, az élettel való elégedettség és a boldogság megtapasztalásának indikátora.

A szubjektív jólléti indikátorok 2013-ban szerepeltek először az Eurostat által mért jólléti mutatók között, bár egyes országokban jóval régebben, már az 1950-es években is lekérdezték a boldogság vagy elégedettség szintjét. Bevezetésüket több évtizedes elméleti vita előzte meg,

Ahhoz, hogy boldogulásunkat az ökológiai határokhoz képest is mérni tudjuk, egy környezeti hatás indikátorra is szükségünk van. Az ökológiai lábnyom azt mutatja meg, hogy adott technológiai feltételek mellett mekkora földterületre van szükség ahhoz, hogy a népesség fogyasztási szintjét biztosítani tudjuk hoszszú távon. Az ökológiai lábnyom tehát fogyasztásunk környezeti hatásának egy összetett mérőszáma. Mértékegysége a globális hektár, mely számításánál figyelembe veszik a termékek előállításához a növénytermesztésre, állattenyésztésre, erdőgazdálkodásra, halászatra felhasznált területet, az infrastruktúrával beépített területet, valamint azt a hipotetikus erdőterületet, amely képes lenne az általunk kibocsátott szén-dioxidot asszimilálni. Magyarországon az egy före eső átlagos ökológiai lábnyom 3,6 globális hektár.

Kutatásunkban az ökológiai lábnyomot valójában nemcsak mint a környezetterhelés mutatóját, hanem mint a fogyasztás materiális, anyagforgalommal járó részének a közelítő mutatóját is alkalmaztuk. Az ökológiai lábnyom feltételezésünk szerint közelebbi kapcsolatban van az anyagi fogyasztással, mint a jövedelem. Az előbbi mutató legnagyobb összetevője például az élelmiszerek megtermeléséhez szükséges terület. A magas jövedelmüek ugyan tudnak többször 
annyit költeni élelmiszerre, mint a kevésbé jómódúak, de mégsem képesek többször annyit enni, mint a kevésbé jómódúak. A KSH adatai szerint a legmagasabb két jövedelmi decilis kg-ban mért fogyasztása szinte minden élelmiszernél kb. megegyezik a középső decilisek értékeivel. A magas árfekvésű sajt ökológiai lábnyoma nem feltétlenül nagyobb, mint az olcsó sajtoké. Az ökológiai lábnyom számítása a cikkek kg-ban mért fogyasztásán, és az ezek előállításához szükséges földterület becslésén alapul, ezért ez a mutató a környezetterhelési és a természetes mértékegységben mért anyagi fogyasztás mértékével is közelebbi rokonságot mutat, mint a jövedelem.

Az anyagi fogyasztás-szubjektív jóllét-ökológiai lábnyom hármas összefüggése arra a kérdésre ad választ, hogy mekkora ökológiai hatással jár jóllétünk biztosítása.

\section{A KUTATÁS HÁTTERE ÉS HIPOTÉZISEI}

Fő kutatási kérdésünk az volt, hogy tetten érhetőek-e olyan csoportok a magyar társadalomban, amelyek magas szubjektív jólléti szinten élnek, de ökológiai lábnyomuk mégis mérsékelt. Ezen túlmenően megfogalmaztunk néhány hipotézist is az ökológiai lábnyom és szubjektív jóllét összefüggésére vonatkozóan. Az ökológiai lábnyom és a szubjektív jóllét között erős korrelációt feltételeztünk az alacsony jövedelemszinteknél, ám feltételezésünk szerint ez a kapcsolat a magasabb jövedelmi szintekre lépve gyengül. Köznapi kifejezéssel élve, a pénz nem boldogít, de a hiánya tehet boldogtalanná. Azokat, akik napi szinten megélhetési gondokkal küzdenek - problémás a számlák fizetése, a minőségi étkezés, ruházkodás stb. -, bizonyára boldogabbá tenné jövedelmük emelkedése. Egy biztonságos jólléti szintet elérve azonban a kapcsolat gyengül. Az ökológiai lábnyom és a szubjektív jóllét közötti korreláció feltételezésünk szerint még gyengébb, hisz adott szintü jövedelem magas anyagi és alacsony anyagi tartalmú szolgáltatásokra is költhető. Magas anyagi tartalmú szolgáltatás például az utazás, annak magas üzemanyagigénye és karbonkibocsátása miatt. Aki viszont jövedelméböl megtakarít, vagy müvészeti értékek vásárlására, esetleg oktatásra költ, az kis anyagi tartalmú fogyasztást valósít meg.

Egy bizonyos jövedelmi szint elérésénél inflexiós pont található, amely után a kapcsolat halványul. A jövedelem nagyon jelentős mértékủ növekedése szükséges ahhoz, hogy a boldogság további mérhető növekedését elöidézzük. Különböző stratégiák nyílnak az egyéni boldoguláshoz, miután az alapvető szükségletek kielégítéséért folytatott küzdelem pontján túljutottunk. A materialista célokat követők növelhetik anyagi fogyasztásukat, ezzel együtt ökológiai lábnyomukat, amely elvezethet a szubjektív jóllét növekedéséhez. A nem materialista célokkal növelhető a boldogság és az élettel való elégedettség az ökológiai lábnyom jelentős növekedé- 
se nélkül is. Feltételezéseink szerint tehát a szubjektív jóllét növelésére az anyagi fogyasztás növelésére irányuló stratégiák, és a kevésbé anyagias, más életcélokat felvonultató stratégiák is rendelkezésre állnak. Mennyire sikeresek ezek a szubjektív jóllét növelésében, és mekkora áruk van az ökológiai lábnyom tekintetében? Mennyire elterjedtek a magyar társadalom különböző rétegeiben? Kutatásunkban klaszterelemzést végeztünk az összefüggések mélyebb struktúrájának feltárására.

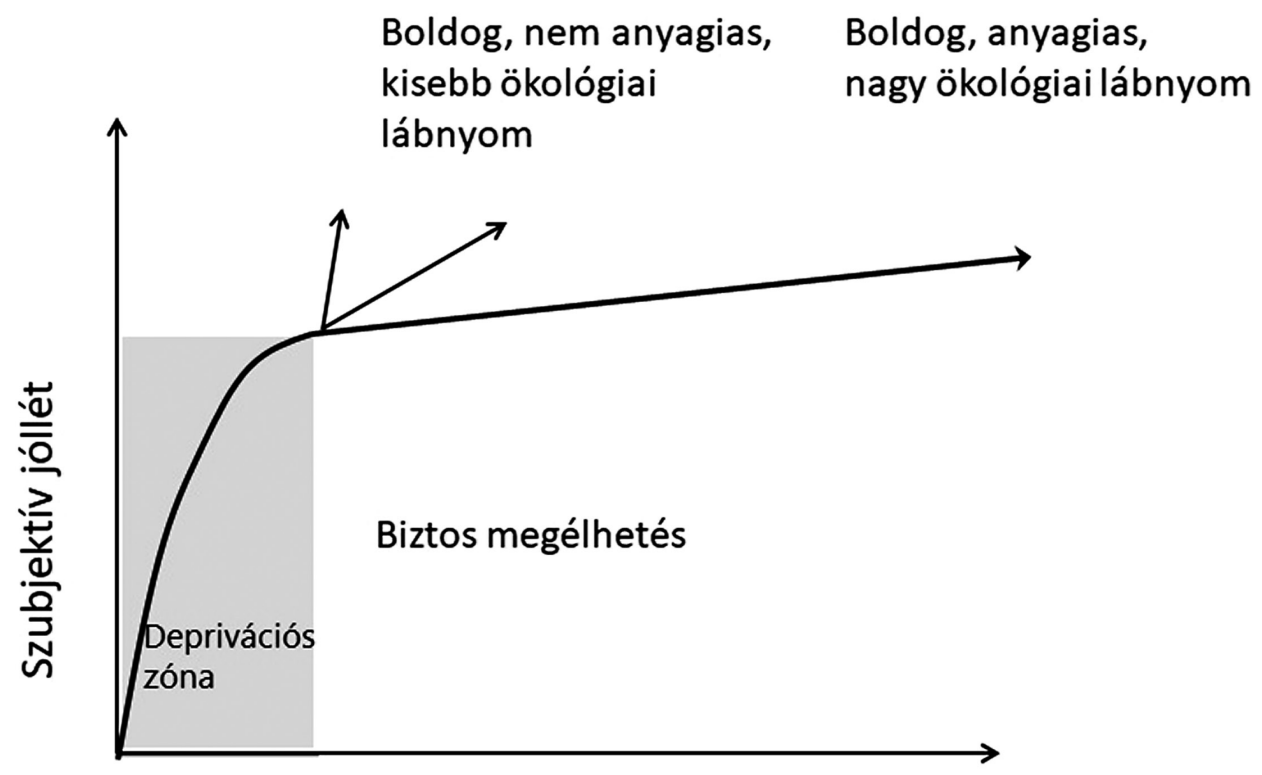

\section{Egy főre eső jövedelem}

1. ábra. Életstratégiák a biztos megélhetési zónában (saját szerkesztés)

\section{AZ EMPIRIKUS ELEMZÉS EREDMÉNYEI}

A kutatás során országos - kétlépcsős, véletlen sétás mintán alapuló - reprezentatív felmérést végeztünk, melyet a TÁRKI segítségével kérdeztettünk le, és 1012 választ kaptunk. A minta életkor, képzettség, nem, lakóhely szerint reprezentatív volt. A felmérésben részletesen lekérdeztük az ökológiai lábnyom komponenseit meghatározó fóbb fogyasztási szokásokat (étkezési szokások, utazási szokások, háztartási energia használata). Ez a három tevékenység teszi ki az ökológiai lábnyom döntő részét, a kisebb tételeket (például ruházkodás) a kiadási szerkezet alapján becsültük. A szubjektív jólléti mutatók közül az élettel való elégedettség- 
re és a boldogság megtapasztalására is rákérdeztünk egy tízfokozatú skála alapján. Végül feltettük a szokásos demográfiai helyzetre vonatkozó kérdéseinket is.

Az eredményekből először az ökológiai lábnyomot számoltuk ki egyéni szinten, majd azt vizsgáltuk, hogy az ökológiai lábnyom milyen kapcsolatban áll a szubjektív jólléttel, a jövedelmi szinttel és a háztartások demográfiai jellemzőivel.

A boldogság és elégedettség közötti monoton kapcsolat erősnek bizonyult (Sperman's rho 0,71), ugyanakkor a boldogság nem volt szignifikáns kapcsolatban sem az egy före eső jövedelemmel, sem pedig az ökológiai lábnyommal. Vagyis a boldogság megtapasztalása nem jövedelemhez kötött, és nem feltétlenül jár magas környezetterheléssel. Az elégedettség és a jövedelem kapcsolata statisztikailag szignifikáns, de gyenge, ami összhangban van a korábbi tanulmányok megállapításaival. Végül az ökológiai lábnyom és az egy fớre eső jövedelem között gyenge-közepes erősségủ a rangkorreláció $($ rho $=0,355)$. Ez azt jelzi, hogy a magasabb jövedelmúekre jellemző a magasabb anyagi fogyasztás és környezetterhelés, viszont a két mutató kapcsolata nem erős, lehetséges kis környezetterhelésủ életmód is magas jövedelem mellett.

Elsőként azt a hipotézist teszteltük, hogy a jövedelem és a szubjektív jóllét közötti korreláció föként az alacsony jövedelmi szinteken erős, majd a magasabb jövedelemi szinteknél gyengül.

Ehhez különböző jövedelemszinteknél két részre osztottuk a mintát, és azt vizsgáltuk, hogy van-e olyan jövedelemszint, amely fölött eltünik a korreláció a jövedelem és az elégedettség/boldogság között. Az egyszerübb interpretáció kedvéért a jövedelmet a mintaátlaghoz képesti \%-ban fejeztük ki. Az egész népességre nézve gyenge pozitív kapcsolat van az elégedettség és az egy före eső jövedelem között, ez a kapcsolat viszont nem szignifikáns, ha csak az átlagjövedelem $110 \%$-a felett élőkre vizsgáljuk. Ez azt jelenti, hogy akik érezhetően az átlag felett élnek, azoknál a jövedelem már nem feltétlenül meghatározó tényezője a szubjektív jóllétnek. Az értékelést bonyolítja azonban, hogy a jövedelem és az elégedettség közötti kapcsolat ismét szignifikánssá válik, ha csak a kifejezetten magas jövedelmü egyénekre vizsgáljuk (átlagjövedelem 200\%-a felett). Ök nyilvánvalóan büszkék az elért eredményeikre. Náluk az ökológiai lábnyom és a jövedelem közötti kapcsolat is erősebb. A boldogság azonban náluk sem asszociál a jövedelemmel. A legszegényebbeknél - az átlagjövedelem 50\%-a alatt élök - ugyanakkor az elégedettség és a jövedelem közötti monoton kapcsolat mellett megjelent a boldogság és jövedelem közötti pozitív kapcsolat is. A pénz hiánya valóban tehet boldogtalanná.

A fenti eredmények azt sejtetik, hogy a szubjektív jóllét, jövedelem és ökológiai lábnyom közötti kapcsolat összetettebb, mint amit egyetlen monoton függvénnyel ábrázolni lenne érdemes. Többféle életstratégia húzódhat a háttérben, melyek feltárására összetettebb feltáró jellegű vizsgálatot érdemes végezni. Ezt követően ezért klaszterelemzést végeztünk. A klaszterképzés célja viszonylag homogén, egymástól jelentősen különböző csoportok létrehozása. 
Az elemzés során többféle klaszterezési technikát is alkalmaztunk. Az elemzést a quick cluster és a two-step cluster eljárásokkal is elvégezve nagyon hasonló eredményeket kaptunk. A következőkben az SPSS kétlépéses klaszterelemzési eljárás eredményeit mutatjuk be. A vizsgálat négy klasztert eredményezett, melyekre a klaszterképző ismérveken túlmenően értékelő, leíró statisztikákat is számoltunk. Az egyszerübb értelmezés kedvéért a táblázatban az egy főre eső jövedelmet és az ökológiai lábnyomot is a mintaátlag százalékában adjuk meg. A szubjektív jóllétet 1-től 10-ig terjedő skálán jelölték meg a válaszadók, ahol a maximális érték a 10 volt. A klasztereket főbb jellemzőik alapján neveztük el.

Az ,átlagosak” szinte minden jellemzője nagyon közel állt a mintaátlaghoz. Egy főre eső jövedelmük, ökológiai lábnyomuk, elégedettségi és boldogságszintjük is közel esik az átlaghoz, bár egy kicsit alatta marad.

Az elégedetlen depriváltakra az alacsony jövedelem, alacsony ökológiai lábnyom és a nagyon alacsony szubjektív jóllét a jellemző. Egy före eső jövedelmük csak mintegy kétharmada az átlagnak, és $75 \%$-ban anyagi gondokra panaszkodnak. Az átlaghoz képest magas a gyerekszám a csoportban. A munkanélküliség vagy rossz munkahely is ebben a csoportban a leggyakoribb. Kiugróan elégedetlenek helyzetükkel, a klaszterre jellemző elégedettségi szint még a 3-as értéket sem éri el a 10 -es skálán. Boldogságra vonatkozó mutatójuk ennél jóval magasabb, de még így is átlag alatti. Alacsony fogyasztásuk miatt ökológiai lábnyomuk is alacsony, csak az átlag 70\%-a.

Az elégedett jómódúaknál az egy före eső jövedelem körülbelül a duplája a társadalom átlagának, és majdnem triplája a depriváltakénak. Magas az ökológiai lábnyomuk is, bár a jövedelemhez képest nem arányosan nagyobb, hisz az anyagi fogyasztás bizonyos összetevői nem tudnak a jövedelemmel arányosan nőni (például az élelmiszer-fogyasztás). Az átlagnál jóval elégedettebbek az életükkel, és boldogok is, bár a boldogság alig haladja meg az elégedettség szintjét, szemben más csoportokkal. Szubjektív jóllétük fő meghatározója az elért eredményeikkel való elégedettség. Ennek valószínüleg az az oka, hogy ebben a csoportban az átlagnál jóval gyakrabban jelennek meg olyan problémák, mint a társtalanság, egészségügyi gondok vagy a társadalmi elszigeteltség. Kiugróan magas a tartós párkapcsolattal nem rendelkezők aránya (44\%), további $6 \%$ pedig boldogtalan párkapcsolatban él, és ennél a csoportnál született átlagosan a legkevesebb gyerek. A csoportba tartozók fele egészégügyi problémákra panaszkodott. A társadalmi elszigeteltségre panaszkodók aránya 19\%, legmagasabb a mintában, a második helyen a legszegényebbek állnak. A munkájukkal viszont maradéktalanul elégedettek, sem a munkanélküliség, sem a rossz munkahely nem jellemző a csoportra, és anyagi gondokra is kevesen panaszkodnak. Úgy tủnik, számításaikat sokkal inkább a karrierben, mint a családi életben találták meg, amely a második legelégedettebb csoporttá tette őket. 
2. táblázat. A klaszterelemzés eredménye (saját szerkesztés)

Klaszterek

Input (elörejelző) fontossága: $\square 1,0 \square 0,8 \square 0,6 \square 0,4 \square 0,2 \square 0,0$

\begin{tabular}{|c|c|c|c|c|}
\hline Klaszterek & 1 & 3 & 4 & 2 \\
\hline Címke & Átlagosak & $\begin{array}{l}\text { Kevéssel is nagyon } \\
\text { elégedettek }\end{array}$ & $\begin{array}{l}\text { Elégedetlen } \\
\text { depriváltak }\end{array}$ & Elégedett jómódúak \\
\hline Leírás & $\begin{array}{l}\text { Szubjektív jóllétük, } \\
\text { jövedelmük, ökológiai } \\
\text { lábnyomuk, és egyéb } \\
\text { mutatóik is átlag } \\
\text { körüliek }\end{array}$ & $\begin{array}{l}\text { Átlag alatti jövedelem } \\
\text { mellett is kiemelkedően } \\
\text { magas a szubjektív } \\
\text { jóllétük. Jó családi } \\
\text { élet és társadalmi } \\
\text { kapcsolatok, több } \\
\text { gyerek jellemzik őket. }\end{array}$ & $\begin{array}{l}\text { Anyagi gondokkal } \\
\text { küszködnek és nagyon } \\
\text { elégedetlenek, több } \\
\text { gyerekük van. }\end{array}$ & $\begin{array}{l}\text { Magas jövedelem és } \\
\text { elégedettség, de csak } \\
\text { átlag körüli boldogság. } \\
\text { Sok a partner nélküli, } \\
\text { az egészségügyi } \\
\text { problémákkal küszködő. } \\
\text { Csak egy gyerekük van. }\end{array}$ \\
\hline Méret & $\begin{array}{l}31,8 \% \\
(142)\end{array}$ & $\begin{array}{l}26,5 \% \\
(118)\end{array}$ & $\begin{array}{l}22,6 \% \\
(101)\end{array}$ & \begin{tabular}{l|l}
$19,1 \%$ \\
$(85)$
\end{tabular} \\
\hline \multirow{2}{*}{$\begin{array}{l}\text { Input } \\
\text { változók }\end{array}$} & $\begin{array}{l}\text { Elégedettség } \\
5,51 \\
\end{array}$ & $\begin{array}{l}\text { Elégedettség } \\
\qquad 7,90\end{array}$ & $\begin{array}{l}\text { Elégedettség } \\
\qquad 2,93\end{array}$ & $\begin{array}{l}\text { Elégedettség } \\
\quad 6,87\end{array}$ \\
\hline & $\begin{array}{c}\text { Egy före jutó jövedelem } \\
\text { az átlag százalékában } \\
90,63\end{array}$ & $\begin{array}{c}\text { Egy före jutó jövedelem } \\
\text { az átlag százalékában } \\
74,22\end{array}$ & $\begin{array}{c}\text { Egy före jutó jövedelem } \\
\text { az átlag százalékában } \\
67,98\end{array}$ & $\begin{array}{c}\text { Egy före jutó jövedelem } \\
\text { az átlag százalékában } \\
\qquad 189,61\end{array}$ \\
\hline \multirow{9}{*}{$\begin{array}{l}\text { Értékelési } \\
\text { mezők }\end{array}$} & $\begin{array}{c}\text { Ökológiai lábnyom } \\
\text { az átlag százalékában } \\
91,96\end{array}$ & $\begin{array}{c}\text { Ökológiai lábnyom } \\
\text { az átlag százalékában } \\
87,50\end{array}$ & $\begin{array}{c}\text { Ökológiai lábnyom } \\
\text { az átlag százalékában } \\
70,55\end{array}$ & $\begin{array}{c}\text { Ökológiai lábnyom } \\
\text { az átlag százalékában } \\
118,58\end{array}$ \\
\hline & $\begin{array}{c}\text { Nincs partnere } \\
0,07\end{array}$ & $\begin{array}{l}\text { Nincs partnere } \\
0,08\end{array}$ & $\begin{array}{c}\text { Nincs partnere } \\
0,15\end{array}$ & $\begin{array}{c}\text { Nincs partnere } \\
0,44 \\
\end{array}$ \\
\hline & $\begin{array}{l}\text { Társadalmi elszigeteltség } \\
\qquad 0,07\end{array}$ & $\begin{array}{c}\text { Társadalmi elszigeteltség } \\
0,04\end{array}$ & $\begin{array}{l}\text { Társadalmi elszigeteltség } \\
0,12\end{array}$ & $\begin{array}{l}\text { Társadalmi elszigeteltség } \\
0,19\end{array}$ \\
\hline & $\begin{array}{l}\text { Egészségügyi } \\
\text { problémák } \\
0,35\end{array}$ & $\begin{array}{l}\text { Egészségügyi } \\
\text { problémák } \\
0,40\end{array}$ & $\begin{array}{l}\text { Egészségügyi } \\
\text { problémák } \\
0,33\end{array}$ & $\begin{array}{l}\text { Egészségügyi } \\
\text { problémák } \\
0,50\end{array}$ \\
\hline & $\begin{array}{l}\text { Rossz anyagi helyzet } \\
0,64\end{array}$ & $\begin{array}{l}\text { Rossz anyagi helyzet } \\
0,60\end{array}$ & $\begin{array}{l}\text { Rossz anyagi helyzet } \\
0,76\end{array}$ & $\begin{array}{l}\text { Rossz anyagi helyzet } \\
0,25\end{array}$ \\
\hline & $\begin{array}{c}\text { Boldogtalan párkapcsolat } \\
0,01 \\
\end{array}$ & $\begin{array}{c}\text { Boldogtalan párkapcsolat } \\
0,00 \\
\end{array}$ & $\begin{array}{c}\text { Boldogtalan párkapcsolat } \\
0,08 \\
\end{array}$ & $\begin{array}{l}\text { Boldogtalan párkapcsolat } \\
\qquad 0,06\end{array}$ \\
\hline & $\begin{array}{c}\text { Munkanélküli vagy } \\
\text { elégedetlen a munkájával } \\
0,28\end{array}$ & $\begin{array}{c}\text { Munkanélküli vagy } \\
\text { elégedetlen a munkájával } \\
0,34\end{array}$ & $\begin{array}{c}\text { Munkanélküli vagy } \\
\text { elégedetlen a munkájával } \\
0,47\end{array}$ & $\begin{array}{c}\text { Munkanélküli vagy } \\
\text { elégedetlen a munkájával } \\
0,00\end{array}$ \\
\hline & $\begin{array}{c}\text { Boldogság } \\
\quad 6,26\end{array}$ & $\begin{array}{c}\text { Boldogság } \\
7,97\end{array}$ & $\begin{array}{c}\text { Boldogság } \\
4,72\end{array}$ & $\begin{array}{c}\text { Boldogság } \\
\quad 6,89\end{array}$ \\
\hline & $\begin{array}{c}\text { Hány gyermeke } \\
\text { született élete során? } \\
1,60\end{array}$ & $\begin{array}{c}\text { Hány gyermeke } \\
\text { született élete során? } \\
1,89\end{array}$ & $\begin{array}{c}\text { Hány gyermeke } \\
\text { született élete során? } \\
1,80\end{array}$ & $\begin{array}{c}\text { Hány gyermeke } \\
\text { született élete során? } \\
1,04\end{array}$ \\
\hline
\end{tabular}


A legérdekesebb csoport a kevéssel is elégedettek csoportja, amelyben az egy főre eső jövedelem az átlag 75\%-a. Ökológiai lábnyomuk ennek ellenére alig kevesebb, mint az átlagosaké, vagyis anyagi fogyasztásukban kevésbé jelentkezik a jövedelembeli elmaradásuk. Ennek oka lehet például, ha az átlagosok közé több olyan egyén kerül, akiknél egy hiteltörlesztés vagy más ok miatt a szabadon elkölthető jövedelem aránya alacsonyabb. A kevéssel is elégedetteknél kiugróan magas mind a bevallott elégedettségi, mind a boldogsági szint (7,9, illetve 7,97). Ebben a csoportban a legmagasabb az átlagos gyerekszám (majdnem kettő). Kevesen vannak olyanok, akiknek nincs tartós párkapcsolatuk, olyan pedig egyáltalán nem került a csoportba, aki boldogtalan párkapcsolatban élne. A munkahellyel való elégedetlenség viszont az átlagot meghaladja a csoportban, és az egészségügyi problémák jelenléte is átlag körüli. Úgy tünik, hogy a legelégedettebb csoport föként a családi életben, a párkapcsolatban, a társadalmi életben találta meg számításait, mérsékelt anyagi fogyasztás és az átlagnál valamivel alacsonyabb ökológiai lábnyom mellett.

Vizsgálataink tehát azt mutatják. hogy létezik a szubjektív jóllét szempontjából nagyon sikeres életstratégia mérsékelt fogyasztás és ökológiai lábnyom mellett is. Bár a jómódúak az átlagnál elégedettebbek, mégsem ők a legelégedettebb és legboldogabb klaszter a mintában. A legelégedettebb klasztert ugyanakkor az átlagnál kisebb ökológiai lábnyom és kiegyensúlyozott magánélet jellemzi.

\section{A KUTATÁS KORLÁTAI}

A kutatás fő korlátját az jelenti, hogy nem volt biztosítható a jövedelem szerinti reprezentativitás a kérdőíves felmérésben, a közvélemény-kutató vállalatok nem vállalják ezt. Különösen a nagyon magas és nagyon alacsony jövedelmü háztartások hajlamosak visszautasítani a válaszadást, a minta így némileg torzított, az alsó és felső jövedelmi decilis alulreprezentált. Vizsgálatainkhoz szükség volt a válaszadók jövedelmének, háztartási jövedelmének ismeretére, erre a kérdésre azonban csak a válaszadók kevesebb mint fele válaszolt, amely egyes elemzéseinkben radikálisan szúkítette a felhasználható minta méretét. Az adott feltételek mellett azonban a legjobb megvalósítható mintavételre támaszkodtunk.

\section{KÖVETKEZTETÉSEK}

A jövedelem és szubjektív jóllét, illetve az ökológiai lábnyom és jövedelemmutatók kapcsolatának leírására hajlamosak vagyunk egyszerü, monoton kapcsolatot keresni, és egyetlen görbével - lineáris vagy logisztikus - ábrázolni azt. Ez a kapcsolat azonban szignifikáns ugyan, de statisztikailag gyenge korreláción 
alapul. A valóságban jóval komplexebb összefüggések uralkodnak, a társadalom különböző klasztereiben eltérő életstratégiák léteznek, amelyek között a szubjektív jóllét növelése szempontjából legsikeresebbre éppen az átlagnál alacsonyabb jövedelem és mérsékelt ökológiai lábnyom jellemző. Lehetséges tehát olyan egyéni stratégiát választani, amely magas szubjektív jóllétet eredményez mérsékelt környezetterhelés mellett. Ez az életstratégia ráadásul nem is ritka, az általunk tanulmányozott mintában az emberek mintegy negyedére volt jellemző.

Eredményeink alapján további érdekes, kutatásra érdemes kérdések merülnek fel. Mennyire tükröz értékbeli választást az egyes klaszterekbe kerülés? Lehetséges-e például az elégedett jómódú klaszterből átkerülni a kevéssel is elégedett klaszterbe az életstílus megváltoztatásával, oly módon, hogy növekedjen a szubjektív jólléti szint? Vagy az adott egyén csak abban a klaszterben érhet el átlag feletti szubjektív jólléti szintet, mivel személyiségi jellemzői erre predesztinálják?

A kutatás implicite azt sugallja, hogy legelőnyösebb stratégia a kevéssel is elégedettek klaszterébe tartozni, de vajon ez mennyire van összhangban az oktatásunk és a média által a jövő nemzedékek felé sugárzott ideálképpel? Ha a fiatalokat a fogyasztói társadalom felé tereljük, akkor nem csökkentjük-e annak esélyét, hogy korlátozott anyagi javak mellett is megéljék az elégedettség érzését?

Kutatásunk hozzájárult a jövedelem, fogyasztás, szubjektív jóllét és ökológiai lábnyom kapcsolatainak mélyebb, árnyaltabb tanulmányozásához, de legalább annyi kérdést vetett fel, mint amennyit meg tudott válaszolni.

\section{IRODALOM}

Bjørnskov, C. - Dreher, A. - Fischer, J. A. V. (2008): Cross-country Determinants of Life Satisfaction: Exploring Different Determinants Across Groups in Society. Social Choice and Welfare, 30, 119-173. DOI: 10.1007/s00355-007-0225-4, https://bit.ly/2SzIuUF

Brown, K. W. - Kasser, T. (2005): Are Psychological and Ecological Well-being Compatible? The Role of Values, Mindfulness, and Lifestyle. Social Indicators Research, 74, 2, 349-368. DOI: 10.1007/s11205-004-8207-8, https://bit.ly/37eiQu1

Easterlin, R. A. (1973): Does Money Buy Happiness? Public Interest, 30, 3-10.

Harangozó G. - Kocsis T. - Csutora M. (2018): How Big Is Big Enough? Toward a Sustainable Future by Examining Alternatives to the Conventional Economic Growth Paradigm. Sustainable Development, 26, 172-181. DOI: 10.1002/sd.1728, https://onlinelibrary.wiley.com/doi/ full/10.1002/sd.1728

Kasser, T. - Ryan, R. M. (1996): Further Examining the American Dream: Differential Correlates of Intrinsic and Extrinsic Goals. Personality and Social Psychology Bulletin, 22, 280-287. DOI: 10.1177/0146167296223006, https://www.academia.edu/24470435/Further_Examining the_American_Dream_Differential_Correlates_of_Intrinsic_and_Extrinsic_Coals

Kasser, T. - Ryan, R. M. (2001): Be Careful What You Wish for: Optimal Functioning and the Relative Attainment of Intrinsic and Extrinsic Goals. In: Schmuck, P. -Sheldon, K. M. (eds.): Life-goals and Well Being. Towards a Positive Psychology of Human Striving. Seattle: Hogrefe 
and Huber, https://www.researchgate.net/publication/232501725_Life_goals_and_well-being_ Towards_a_positive_psychology_of_human_striving

Kocsis T. (2010): Hajózni muszáj. A GDP, az ökológiai lábnyom és a szubjektív jóllét stratégiai összefüggései. Közgazdasági Szemle, LVII, 536-554. http://unipub.lib.uni-corvinus.hu/220/1/ Kszemle_CIKK_1175.pdf

Lelkes O. (2014): Boldog-boldogtalan - a közpolitika szerepe. Közgazdasági Szemle, 61, 13811396. http://real.mtak.hu/18814/1/01_Lelkes_Orsolya_u_151924.2297.pdf

Martos T. - Kopp M. S. (2012): Life Goals and Well-being: Does Financial Status Matter? Evidence from a Representative Hungarian Sample. Social Indicators Research, 105, 561-568. DOI:10.1007/s11205-011-9788-7, https://bit.ly/2tN6eMB

Molnár Gy. - Kapitány Zs. (2014): Miért elégedetlenek annyira a magyarok az életükkel? Közgazdasági Szemle, 61, 6, 637-671. http://real.mtak.hu/13506/1/Kszemle_CIKK_1485\%20 $\% 281 \% 29$.pdf

Nickerson, C. - Schwarz, N. - Diener, E. et al. (2003): Zeroing in on the Dark Side of the American Dream: A Closer Look at the Negative Consequences of the Goal for Financial Success. Psychological Science, 14, 531-536. DOI: 10.1046/j.0956-7976.2003.psci_1461.x, https://pdfs.semanticscholar.org/ff43/f020ce384fd9de3ff895fd09c101ff401e9b.pdf? $\mathrm{ga}=2.63208943 .1370617414 .1581418659-240194266.1562240455$

O'Brien, C. (2010): Sustainability, Happiness and Education. Journal of Sustainability Education, 1, 1-18. http://www.jsedimensions.org/wordpress/wp-content/uploads/2010/04/OBrien2010.pdf

Tóth G. - Szigeti C. - Harangozó G. et al. (2018): Ecological Footprint at the Micro-Scale-How It Can Save Costs: The Case of ENPRO. Resources, 7, 45. DOI: 10.3390/resources7030045, https://www.mdpi.com/2079-9276/7/3/45/htm

Veenhoven, R. (2008): Sustainable Consumption and Happiness. In: Reddy, S. (ed.): Green Consumerism: Approaches and Country Experiences, Hyderabad, India: The Icfai University Press, 39-68. https://personal.eur.nl/veenhoven/Pub2000s/2008k-full.pdf

Veenhoven, R. - Hagerty, M. (2006): Rising Happiness in Nations 1946-2004: A Reply to Easterlin. Social Indicators Research, 79, 421-436. DOI: 10.1007/s11205-005-5074-x, https:// www.researchgate.net/publication/225579498_Rising_Happiness_in_Nations_1946-2004_A_ Reply_to_Easterlin

Verhofstadt, E. - Van Ootegem, L. - Defloor, B. et al. (2016): Linking Individuals' Ecological Footprint to Their Subjective Well-being, Ecological Economics, 127, 80-89. DOI: 10.1016/j. ecolecon.2016.03.021, https://www.researchgate.net/publication/301705687_Linking_individuals'_ecological_footprint_to_their_subjective_well-being

Wackernagel, M. - Monfreda, C. - Schulz, N. B. et al. (2004): Calculating National and Global Ecological Footprint Time Series: Resolving Conceptual Challenges, Land Use Policy, 21, 3, 271-278. DOI: 10.1016/j.landusepol.2003.10.006, https://www.mdpi.com/2079-9276/7/3/58/htm 